\title{
Changes in plasma enzyme activities in professional racing cyclists
}

Departamento de Fisiología, Facultad de Medicina, Universidad de Extremadura 06071 Badajoz, Spain P Mena, research assistant M Maynar, research assistant J E Campillo, professor Correspondence to: Primitivo Mena Arias. Accepted for publication 3 October 1995

\begin{abstract}
Objective-To reports changes in plasma levels in professional racing cyclists. Methods-Plasma levels of the intracellular enzymes aspartate aminotransferase, alanine aminotransferase, $\gamma$ glutamyl transpeptidase, lactate dehydrogenase, and alkaline phosphatase were measured resting and after exercise in professional cyclists participating in two road races: Vuelta Ciclista a Valencia $(800 \mathrm{~km}$, beginning of the cyclist season), and the top rank race Vuelta a España $(2700 \mathrm{~km}$, at the end of cyclist season).
\end{abstract}

Results-A significant increase in plasma aspartate aminotransferase, alanine aminotransferase, and alkaline phosphatase was observed at the end of the race over the corresponding paired start values $(P<0.05)$. The increase in plasma lactate dehydrogenase after the race was only statistically significant $(P<0.05)$ in the Vuelta a España. The longer the duration of the cycle tour race, the greater were the increases in aspartate aminotransferase and alanine aminotransferase levels. The high levels returned to their start values during the overnight resting period. Conclusions-The presence of these enzymes in the blood is probably due to mechanically damaged muscle cells leaking their contents into the interstitial fluid. (Br F Sports Med 1996;30:122-124)

Key terms: plasma enzymes; exercise; cycling

It is well established that there is an increase in plasma activities of various intracellular enzymes after long term physical exercise. ${ }^{1}$ Apart from the value that measurement of these variables has for the sportsmen and women themselves and for sport in general, there are also major clinical implications. There are, however, remarkable differences in the degree to which plasma enzyme activities increase with exercise. Intensity, duration, and type of exercise, and individual variability are the most important determining factors. ${ }^{1}$

In contrast to the well defined effect of acute exercise, there is little information on the effect of chronic exercise on intracellular enzyme plasma levels, and only a few studies have been performed during real professional trials. ${ }^{2-4}$

We had a unique opportunity to investigate the changes in plasma activity levels of the intracellular enzymes aspartate aminotransferase (AST), alanine aminotramsferase (ALT), $\gamma$ glutamyl transpeptidase (GGT), lactate dehydrogenase (LDH), and alkaline phosphatase (ALP) in professional cyclists who were competing in two races of different lengths: the Vuelta Ciclista a Valencia $(800 \mathrm{~km} /$ 6 days) and the Vuelta Ciclista a España (2700 $\mathrm{km} / 20$ days).

\section{Methods}

The professional cyclists were participants in two races of different lengths, the "Vuelta Ciclista a Valencia" (VCV, 800 km, 6 days, in February, at the beginning of the cycling season, $n=34$ ) and the top rank "Vuelta Ciclista a España" (VCE, 2700 km, 20 days, in May, at the end of the cycling season, $\mathrm{n}=15$ ), and a stage of the Vuelta Ciclista a España (234 km/5 h, $n=17)$. Informed consent was obtained from all subjects and from the medical staff of the cycling teams.

Blood samples $(10 \mathrm{ml})$ were drawn from an antecubital vein into chilled tubes containing $3.8 \%$ sodium citrate as anticoagulant. The blood was immediately centrifuged at $4^{\circ} \mathrm{C}$ and $840 \mathrm{~g}$ for $10 \mathrm{~min}$ to separate cells from plasma. There was no visible haemolysis in the samples, and this was verified by plasma haemoglobin determination. Basal samples were obtained on the first day of the race after an overnight fast, when subjects were resting, and in most cases when the cyclist was still in bed at the hotel. Post-race samples were obtained immediately, within $30 \mathrm{~min}$ after the end of the corresponding stage, before the cyclists had lunch. In the case of the single stage, samples were taken at the beginning and end of the stage, as in the previous case, and a third sample on the following day, after the night's rest.

AST, ALT, GGT, and ALP activity assays were carried out using products from Böehringer Mannheim for automated methods. $\mathrm{LDH}$ was assayed using a commercial kit from Böehringer Mannheim for manual analysis.

All results are expressed as mean(SD). The statistical analysis was performed by the Wilcoxon test for paired data.

\section{Results}

Table 1 shows the changes observed in plasma AST, ALT, LDH, ALP, and GGT activities in 17 cyclists at the start and end of a $234 \mathrm{~km}$ stage. The last column shows the enzyme activities on the following morning, before the start of the next stage. An increment of high level of significance $(P<0.001)$ in AST and ALP and also a significant rise $(P<0.05)$ in ALT were observed after the stage. On the following morning, the levels had returned to the resting values. 
Table 1 Plasma levels of aspartate transaminase (AST), alanine transaminase (ALT), lactate dehydrogenase $(L D H)$, alkaline phosphatase $(A L P)$, and $\gamma$ glutamyltransferase (GGT) in 17 cyclists at the beginning and at the end of a $234 \mathrm{~km}$ stage of the Vuelta Ciclista a España and 24 h later, before starting the next stage (recuperation). Values are means (SD)

\begin{tabular}{lccc}
\hline Enzyme $(\mathrm{mU} / \mathrm{ml})$ & Start & End & Recuperation \\
\hline AST & $20(7)$ & $25(6)^{\star \star}$ & $21(7) \dagger$ \\
ALT & $23(8)$ & $27(7)^{\star}$ & $23(9) \dagger$ \\
LDH & $129(21)$ & $137(25)$ & $118(39)$ \\
ALP & $50(10)$ & $68(17)^{\star \star}$ & $59(11) \mathrm{t \dagger}$ \\
GGT & $11(2)$ & $8(3)$ & $8(2)$ \\
\hline
\end{tabular}

$\star \star \mathrm{P}<0.001 v$ start $+\mathrm{P} \mathrm{P}<0.01 v$ end

$\star \mathrm{P}<0.05 v$ start $+\mathrm{P}<0.05 v$ end

Table 2 shows the chronic changes observed in the levels of these enzyme activities at the start and at the end of two races of different length and duration. GGT did not change significantly, while the AST, ALT, ALP, and $\mathrm{LDH}$ activities increased at the end of the races compared with the corresponding start values.

The longer the duration of the cycle tour race, the greater were the increases in plasma AST, ALT, and LDH.

Plasma malondialdehyde values increased at the end of the single stage $[18.00(1.91) v$ $6 \cdot 76(0 \cdot 84) \mathrm{mM}]$, as well as at the end of the VCE $[10.08(1.14) v 4.84(0.65) \mathrm{mM}]$ and the $\operatorname{VCV}[7 \cdot 34(0 \cdot 99) v 4 \cdot 04(0 \cdot 38) \mathrm{mM}]$.

\section{Discussion}

The increase in plasma enzyme activities after physical exercise has been well established in various studies. Several hypotheses have been proposed to account for the presence in plasma of high levels of enzyme activities with a generally intracellular origin. The hypoxia hypothesis, ${ }^{5-7}$ changes in membrane permeability after brief exercise, ${ }^{8}$ and cellular damage by either exercise induced mechanical proccesses ${ }^{9}$ or by oxygen free radical induced lipoperoxidation processes $^{10-13}$ have been invoked as explanations.

The present results show that there was a rise in AST, ALT, LDH, and ALP activities in plasma as a consequence of both acute and chronic exercise.

The results after acute exercise concur with those of other workers ${ }^{1415}$ who used ergometric tests to show that there exist temporary increments in AST, ALT, and LDH after acute exercise.

In acute exercise (the stage), these activities decrease after the recovery period (from the end of stage to the start of the before next), but they do not return to the basal values. This

Table 2 Plasma levels of aspartate transaminase (AST), alanine transaminase (ALT), lactate dehydrogenase $(L D H)$, alkaline phosphatase (ALP) and

$\gamma$ glutamyltransferase (GGT) in professional cyclists before and after two races of different duration. Values are means (SD)

\begin{tabular}{|c|c|c|c|c|}
\hline \multirow[t]{2}{*}{$\begin{array}{l}\text { Enzyme } \\
(m U / m l)\end{array}$} & \multicolumn{2}{|c|}{$\begin{array}{l}\text { VCV race, } 800 \mathrm{~km} \\
(n=34)\end{array}$} & \multicolumn{2}{|c|}{$\begin{array}{l}V C V \text { race, } 2700 \mathrm{~km} \\
(n=15)\end{array}$} \\
\hline & Start & End & Start & End \\
\hline $\begin{array}{l}\text { AST } \\
\text { ALT } \\
\text { LDH } \\
\text { ALP } \\
\text { GGT }\end{array}$ & $\begin{array}{l}25(8) \\
22(8) \\
98(22) \\
60(14) \\
9(4)\end{array}$ & $\begin{array}{c}34(14)^{\star} \\
27(7) \dagger \\
108(23) \\
82(14) \ddagger \\
9(2)\end{array}$ & $\begin{array}{c}21(6) \\
21(9) \\
138(35) \\
53(12) \\
11(2)\end{array}$ & $\begin{array}{c}43(8) \ddagger \\
34(6) \ddagger \\
162(31)^{\star} \\
64(14) \dagger \\
11(3)\end{array}$ \\
\hline
\end{tabular}

shows that there is a cumulative effect during a race with several stages, illustrated by the finding that the enzyme increments seem to depend on the length of the race (number of stages) and, in general, on the duration of the exercise. ${ }^{14} 15$

The starting values in the two races were similar, with a separation in time of two months. This indicates that the increases in these enzymes are reversible with the values returning to the basal level after several days of rest between trials. No differences were found in the resting values when obtained with subjects recumbent or in the supine position. In both situations, the subject was in the hotel room, having made only a minimum of movements.

An important fact, shown in table 2, is the increase in AST and $\mathrm{LDH}$ at the beginning of the season during early training $(800 \mathrm{~km}, \mathrm{VCV}$ race) with respect to the late races $(2700 \mathrm{~km}$, VCE race). This is probably due to the start of training after two to three months of relative rest.

The plasma AST, ALT, and LDH activities correlated positively at the beginning and, even more so, at the end of the trials, when increases are detected (AST/ALT, $r=0.87, \mathrm{P}<0.0001$; AST/LDH, $r=0.71, \mathrm{P}<0.005 ; \mathrm{ALT} / \mathrm{LDH}$, $r=0.63, \mathrm{P}<0.01)$. These enzyme levels also correlated at the end of stage (AST/ALT, $r=0.61, \quad \mathrm{P}<0.01 ; \quad$ AST/LDH, $\quad r=0.55$, $\mathrm{P}<0.05 ; \quad$ ALT/LDH, $r=0.67, \quad \mathrm{P}<0.005)$. These would be explained by assuming that these increases have a common origin for this entire enzyme group. However, ALP - which is increased by acute and chronic exercise - was not correlated with the other enzymes. The causes of the rise in this enzyme are still unknown, but its origin is probably not the same as that of AST, ALT, and $\mathrm{LDH}$, which are muscular in origin.

The presence of these enzymes in the blood supply is probably due to mechanically damaged muscle cells leaking their contents into the interstitial fluid. It is unlikely that peroxidation of membrane lipids and further cytolysis is involved in the cause of these processes since there was no correlation between the increments in the plasma enzymes and the malondialdehyde levels (a peroxidation marker), as measured in all the cyclists.

This study was partially supported by a grant (SAF-581/92) from the Comision Interministerial de Ciencia y Tecnologia, Spain.

1 Noakes TD. Effect of exercise on serum enzyme activities in humans. Sports Med 1987;4:245-67.

2 Wolf PL, Lott JA, Nitti GJ, Bookstein R. Changes in serum enzymes, lactate and haptoglobin following acute physical exercise stress in international-class athletes. Clin Biochem 1987;20:73-7.

3 Ohkuwa T, Miyamura M. Plasma LDH isozyme after 400-m sprinting in long-distance runners and untrained subjects. Эpn $\mathcal{F}$ Physiol 1986;36:391-5.

4 Green HJ, Reichmann H. Differential response of enzyme activities in rat diaphragm and intercostal muscles to exercise training. $\mathcal{F}$ Neurol $S c i 1988 ; 84: 157-65$.

5 Gardner GW, Bratton R, Chowdhury SR, Fowler WM, Pearson CM. Effect of exercise on serum enzyme levels in trained subjects. F Sports Med Phys Fit 1964;4:103-10. physical exercise. BMF 1965;i:1653-4.
phe kinase and Fowler WM, Gardner GW, Kazerunian HH, Lauvstad WA. The effect of exercise on serum enzymes. Arch Phys Med Rehabil 1968;49:554-65. 
8 Haralambie G. Neuromuscular irritability and serum creatine phosphate kinase in athletes in training. Int $\mathfrak{f}$ Rehab Res 1973;31:279-88.

9 Friden J, Sjostrom M, Ekblom B. Myofibrillar damage following intense eccentric exercise in man. Int $\mathcal{f}$ Sports Med 1983;4:170-6.

10 Kanter MM, Kaminsky LA, Laham-Saeger J, Lesmes GR Nequim ND. Serum enzyme levels and lipid peroxidation in ultramarathon runners. Ann Sports Med 1986;3:39-41.

11 Kanter MM, Lesmes GR, Kamisky LA, Laham-Saeger J, Nequin ND. Serum creatine kinase and lactate dehydrogenase changes following an eighty kilometer race. Eur $\mathcal{F}$ Appl Physiol 1988;57:60-3.
12 Jenkins RR. Free radical chemistry. Relation to exercise. Sports Med 1988;5:156-70.

13 Vinikka L, Vuori J, Ylikorkala O. Lipid peroxides, prostacyclin and tromboxane A2 in runners during acute tacyclin and tromboxane A2 in runners during acute

14 Koutedakis Y, Raafat A, Sharp NC, Rosmarin NM, Beard MJ, Robbins SW. Serum enzyme activities in individuals with different levels of physical fitness. $\mathcal{F}$ Sports Med Phys Fitness 1993;33:252-7.

15 Oguz Karamizrak S, Ergen E, Ruhi Tore I, Akgun N. Changes in serum creatine kinase, lactate dehydrogenase and aldolase activities following supramaximal exercise in athletes. $\mathcal{F}$ Sports Med Phys Fitness 1994;34:141-6.

\section{OCCASIONAL PIECE}

\section{Clinical Tests in Sports Medicine}

\section{Achilles tendon rupture}

The Achilles tendon in the thickest tendon in the body and the tendon most commonly ruptured. In certain cases, however, up to $25 \%$ of these injuries are initially missed, particularly if a palpable gap is not evident.

\section{ACTIVE PLANTAR FLEXION TEST (AGAINST GRAVITY)}

If a standing patient is asked to actively plantarflex to stand in a "tiptoe" position, there is reduced plantarflexion on the side of the tendon rupture. Although false negatives are rare, false positives are common due to reflex inhibition from other pathologies in the region of the ankle joint and calf.

SIMMONDS' OR THOMPSON'S SQUEEZE TEST This test was initially described by Simmonds in 1957 and Thompson and Doherty in 1962. With the patient lying prone and ankles clear of the examination couch the examiner squeezes the patient's calf. In an intact musculotendinous unit, plantarflexion of the ankle joint will occur, this effect being absent or markedly reduced in the presence of Achilles tendon rupture. Unfortunately a false negative result can occur in the presence of an intact plantaris tendon.

\section{COPELAND'S TEST}

This was initially described in 1990 and consists of insufflation of a sphygmomanometer cuff around the mid-calf, with the patient relaxed in the prone position. The cuff is inflated to $100 \mathrm{~mm} \mathrm{Hg}$ with the foot in plantarflexion. Dorsiflexion in the presence of an intact Achilles tendon results in raised pressure to approximately $140 \mathrm{~mm} \mathrm{Hg}$, while the pressure remains unchanged in the presence of a complete Achilles tendon rupture.

Although these tests are sensitive, particularly in the acute rupture, they can be more difficult to assess in the presence of delayed rupture with incomplete healing. Imaging with real time ultrasound or magnetic resonance may in these circumstances be helpful in further assessment; ultrasound has the advantage of being an easier dynamic study. 